\title{
Holocord Ependymoma
}

\author{
Holokord Ependimom
}

Hamit Feran GUNES, Nail OZDEMIR

Izmir Ataturk Training and Research Hospital, Department of Neurosurgery, Izmir, Turkey

Correspondence address: Hamit Feran GUNES / E-mail: hgferan@gmail.com

\begin{abstract}
Intramedullary tumors affecting the entire cord from the cervicomedullary junction to the conus are termed "holocord tumors". Ependymomas are the most frequent intramedullary tumor in adults. Holocord ependymoma is an exceedingly rare condition. An extensive review of the literature revealed that only five other cases have been reported. We report the sixth case of holocord ependymoma. In this article, we present a case of holocord ependymoma in a 19-year-old girl which was totally resected in a two-stage approach. A two-staged operation is recommended for the aim of total resection for this disease. Besides, cysts are common feature of all spinal ependymomas. There was a solid mass not accompanied by a cyst a any level in our patient's tumor. To the authors' best knowledge, a pure solid mass not accompanied by a cyst has not been previously reported with holocord ependymoma cases.
\end{abstract}

KEYWORDS: Ependymoma, Holocord, Intramedullary, Spinal tumor

öz

Servikomedüller bileşkeden konusa kadar tüm kordu tutan intramedüller tümörler "holokord tümörler" olarak adlandırılır. Ependimomlar, yetişkinlerin en sık rastlanan intramedüller tümörleridir. Holokord ependimom, oldukça nadir rastlanan bir durumdur. Geniş literatür taramasında, daha önceden sadece beş vaka bildirildiği görülmüştür. Biz holokord ependimomlu altıncı vakayı sunduk. Bu yazıda, iki aşamalı yaklaşımla total rezeksiyon uyguladığımız holokord ependimomu olan 19 yaşındaki kız vakayı sunduk. Total rezeksiyon amacıyla, bu hastalık mevcudunda iki aşamalı operasyon önerilir. Ayrıca, kistler spinal ependimomların en önemli özelliğidir. Bizim hastamızın tümöründe, tüm seviyelerde kistik alan içermeyen solid kitle mevcuttu. Bu yazının yazarlarının bilgisine göre, daha önce bildirilen holokord ependimomlu vakalarda kistik alan içermeyen solid kitle bildirilmemiştir.

ANAHTAR SÖZCÜKLER: Ependimom, Holokord, İntramedüller, Spinal tümör

\section{INTRODUCTION}

Intramedullary tumors affecting the entire cord from the cervicomedullary junction to the conus are termed "holocord tumors"(11). Holocord ependymoma is very rare and only five cases have been reported in the literature $(3,4,5,7,12)$. It was described by Cushing (3) in 1927. Since then, four additional cases have been reported $(4,5,7,12)$. We report the sixth case of holocord ependymoma. Fischer et al. (4) reported two cases of ependymoma using the term "pan-spinal" tumor. Tedeschi et al. (13) reported that panspinal intramedullary astrocytoma, which was a solid mass not accompanied by a cyst, was named as a"pan-medullary" tumor. In our case, there was a pure solid mass not accompanied by a cyst at any spinal segment. To the authors' best knowledge, this feature has not been described previously. The goal of this article is to report our case and discuss the diagnosis, treatment and prognosis.

\section{CASE REPORT}

A 19-year-old girl with back pain and extremity weakness was admitted to our institution. Her complaints had started two years previously and there had been rapid increase of her symptoms in the last month. Neurological examination revealed 4/5 motor function at bilateral upper and lower extremities. Sensory level was D6. The deep tendon reflexes were hyperactive. Babinski sign was present bilaterally. Our patient's neurological status was evaluated using the classification scheme developed by McCormick et al. (6); in brief, grade 1: neurologically normal, no sensory or motor deficit; Grade 1b: mild sensory-motor deficit; Grade 2: sensorimotor deficit affecting the function of the involved limb; Grade 3: more severe neurologic deficit, with a brace required for ambulation; and Grade 4: severe deficit, with wheelchair required. Our patient was grade 2 preoperatively. Magnetic resonance imaging (MRI) of the spine showed a diffuse intramedullary mass involving the cervico-medullary region to the conus medullaris enhancing heterogeneously on contrast administration. The T1- and T2-weighted images (T1W, T2W) revealed hipointensity and hiperintensity, respectively (Figure $1 \mathrm{~A}-\mathrm{C}$ ). During surgery, through a osteoplastic laminoplasty that extended between $\mathrm{C} 1$ and L2 (first stage: C1-Th4, second stage: Th5-L2) and with standard microsurgery techniques, the intramedullary tumor was located within the cervical cord, thoracic cord and the conus medullaris was removed totally. The tumor was soft, gray, diffuse, and poorly vascular. There was no cystic areas within the tumor (Figure 2). We used a Cavitron ultrasonic surgical aspirator (CUSA) to debulk the tumor aiming to protect the 


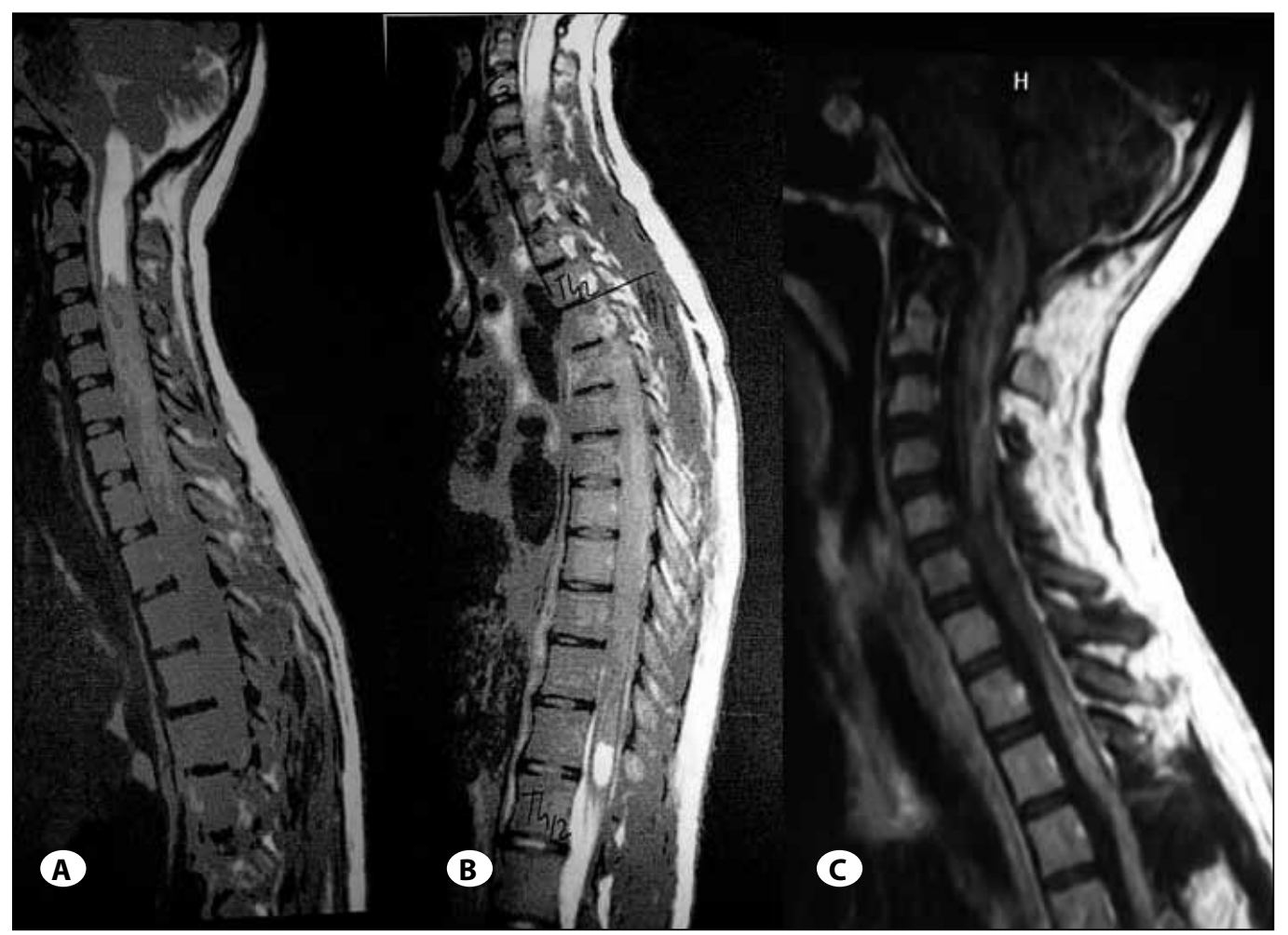

Figure 1: Preoperative MRI: Sagittal T2W of cervicothoracal (A, B), and gadolinium enhanced sagittal T1W cervicothoracal (C) spine images showed a heteregenously solid tumor extending from the cervicomedullary junction to the conus medullaris.

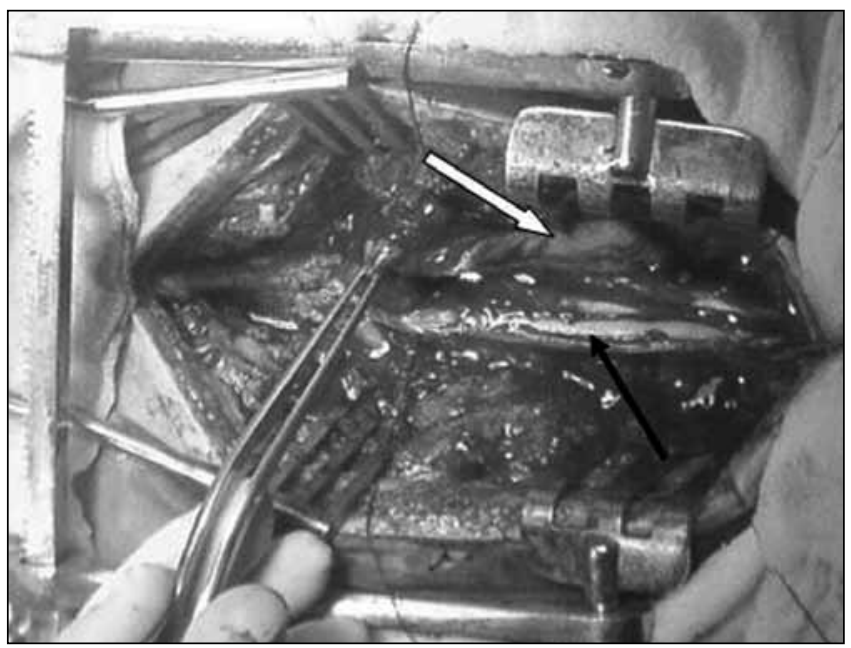

Figure 2: Operative photograph, showing a solid, soft, gray tumor (white arrow) in the cervical spinal cord (black arrow).

cord from surgical damage. If a cleavage plane was found, the tumor was ablated with a CUSA at low suction. After debulking, the peripheral parts of the mass were dissected from the cord using plated bayonettes and microforceps. Feeding vessels were on the anterior side of the tumor. After the tumor was completely excised, care was taken to ensure hemostasis. Dura was primarily closed. The histopathological examination revealed a ependymoma. Our patient exhibited additional motor and sensory deficit after the surgery.
The early postoperative period showed that our patient deteriorated to Grade 3 of the McCormick classification. Early physical rehabilitation was used for our patient. Neurological recovery from the operative deficit was achieved within 3 months after surgery and continued within the first year. Motor weakness improved more rapidly than sensory deficit and posterior column dysfunction. At the last follow-up, two years after the operation, the patient exhibited Grade 2 status. A postoperative MRI and plain X-ray of the cervical, thoracal, lumbar areas were taken two years later and recurrence of the tumor and spinal deformity requiring surgical correction had not occurred (Figure 3A, B).

\section{DISCUSSION}

Ependymomas are the most frequent intramedullary tumor in adults. Astrocytomas are two or four times more frequent than ependymomas in children and young adults (9). Holocord ependymoma is extremely rare and only five cases have been reported $(3,4,5,7,12)$. We report the sixth case of holocord ependymoma. The details of these patients are summarised in Table I.

Cysts (tumoral or non-tumoral) are common feature of all spinal ependymomas (10). It is important to differentiate tumoral cysts from other types. Although intratumoral cysts may require surgical excision, rostral or caudal nontumoral cysts do not require excision. According to Sarikaya et al. (10), the accompanying syrinx will decrease in size automatically when the tumor is removed totally. All holocord 


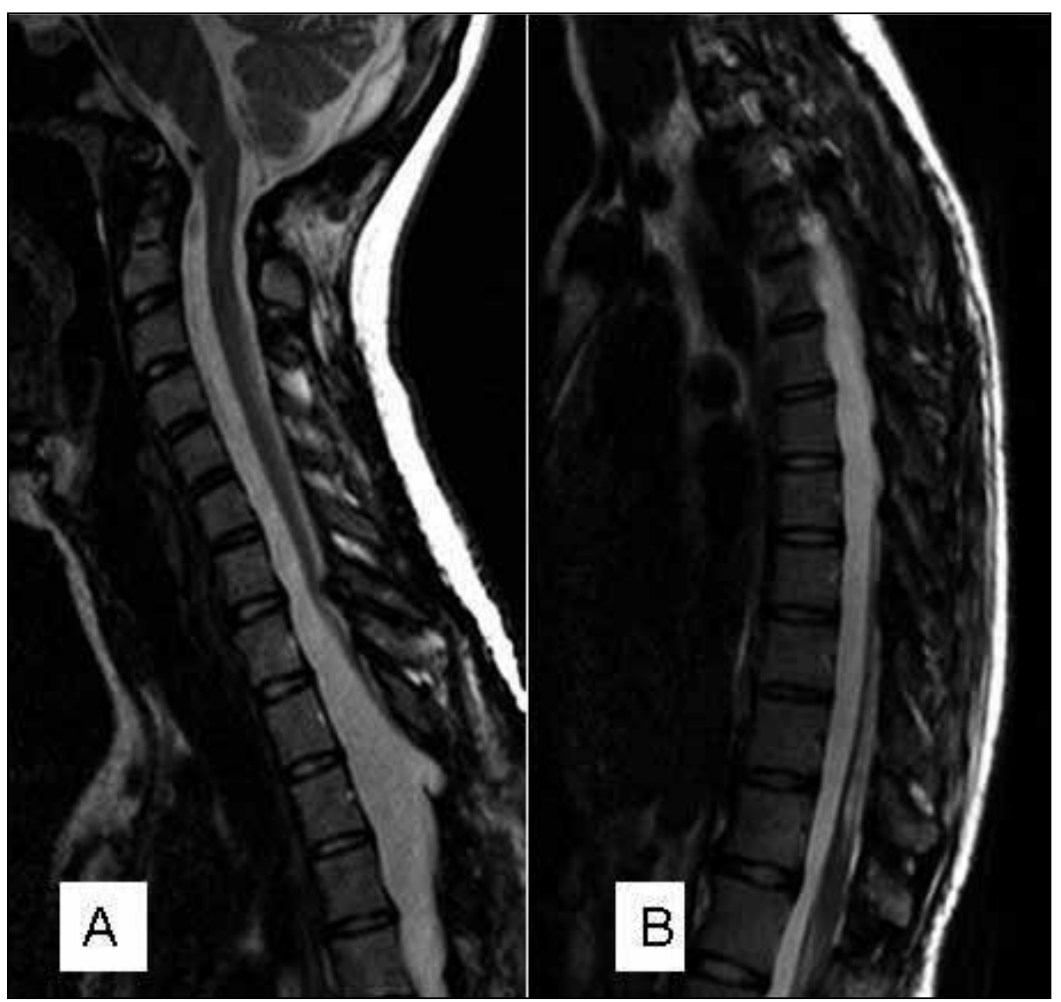

Figure 3: Postoperative MRI:T1W sagittal images of cervical (A) and thoracolumbar (B) spine showed complete resection of the tumor. There was no recurrence of the tumor after two years.

ependymoma cases in the literature had a cyst extending over several vertebrae. In contrast, there was a solid mass not accompanied by a cyst at any level in our patient's tumor.

MRI remains the best imaging modality to diagnose spinal cord ependymoma. Ependymomas may be hypointense or isointense to spinal cord on T1W images while hyperintense on T2W images. Signal heterogeneity may be due to areas of cystic degeneration or hemorrhage. Contrast is also helpful in visualizing intratumoral cysts because enhancement will be seen around them, unlike around caudal and rostral cysts which do not enhance. Homogeneous or heterogeneous enhancement is noted after contrast enhancement (2). The MRI findings in our patient were similar to those of previous reports of spinal intramedullary ependymomas.

Gross total resection of holocord intramedullary tumors can be achieved with preservation of long-term neurological status in many cases. Surgery at an early stage should be recommended (14). However, it is problematic to recommend surgery when the patient has no preoperative neurological deficit. Staged surgeries may be beneficial for holocord ependymomas. The two stages will typically entail a cervical and a thoracic surgery. If a large lesion (more than 15 vertebral levels) is involved and the patient is not very small in size, staging allows the surgeon to focus on a smaller lesion, which will cut down on anesthesia time, and avoid to trauma on neural tissues, and this may result in a more total excision (14). Holocord ependymomas were totally resected with twostaged operations in four patients in the literature. Fischer et al. (4) performed total excision of the tumor in his case in a single operation.
In patients with ependymomas, the outcome depends strictly on the completeness of removal. The most important prognostic factor in determining postoperative neurological status in the long-term is the patient's functional status at surgery, hence the need for an early diagnosis (9). In a series of 21 intramedullary ependymoma cases, Peker et al.(8) identified correlation of tumor parameters (tumor length, tumor width, cyst length, largest cord width at the tumor site, extent of edema in the cord) with neurological status. The patients with wider tumors had poorer preoperative neurological condition and poorer neurological outcome. Tumor length was not correlated with preoperative neurological status, but longer length was significantly associated with development of dysesthesia post surgery. In contrast to tumor length, tumor/ cord ratio (ratio of the tumor width to the largest cord width at the tumor site) was identified as a significant predictor of preoperative neurologic status and outcome. Ratio values of $>0.80$ were correlated with poorer preoperative clinical status and poorer neurologic outcome. Neither extent of edema nor presence of a cyst in the tumor was significant relative to postoperative neurological recovery in these cases. Aghakhani et al. (1) reported on 82 adult patients of intramedullary ependymomas from a single institution during a 15-year period. This authors investigated outcomes in patients who underwent operations for tumors that only presented with pain and no neurological motor or sensory deficits. However, these authors focused on 10 patients with a normal preoperative neurological examination (group B). At the immediate assessment after surgery, conditions in $70 \%$ of patients in group B worsened; however, at the last follow- 
up, $90 \%$ of the patients returned to their baseline McCormick scale levels. Tobias et al. (14) recommended serial imaging for detecting tumor recurrence and stabilization of progressive spinal deformity. We described herein a case of holocord ependymoma in a young female patient where the lesion was totally removed with a two-stage operation. The early postoperative period showed that our patient worsened to Grade 3 of the McCormick scale levels. Neurological recovery from the operative deficit was achieved within 3 months after surgery and continued within the first year with the early and aggressive physical rehabilitation. Two years after the operation, our patient exhibited Grade 2 status. There was no recurrence of tumor and spinal deformity.

\section{CONCLUSION}

There are numerous cases of intramedullary ependymomas described in the literature, but holocord ependymoma is uncommon. To our knowledge, a patient with a holocord ependymoma not accompanying cyst has not been reported so far. A two-staged operation is recommended for the aim of total resection. It is important to perform a radical tumor resection in order to either cure the patient or to avoid any further treatment.

\section{REFERENCES}

1. Aghakhani N, David P, Parker F, Lacroix C, Benoudiba F, Tadie M: Intramedullary spinal ependymomas: Analysis of a consecutive series of 82 adult cases with particular attention to patients with no preoperative neurological deficit. Neurosurgery 62:1279-1285, 2008

2. Bloomer CW, Ackerman A, Bhatia RG: Imaging for spine tumor and new application. Top Magn Reson Imaging 17:69-87, 2006

3. Cushing $\mathrm{H}$ : The intracranial tumors of preadolescence. Amer. J Dis Children 33:551-584, 1927

4. Fischer G, Pierluca $P$, Sindou $M$, Pialat J: Pan-spinal ependymoma. Apropos of 2 cases with complete exeresis. Neurochirurgie 21:5-20, 1975
5. Horrax G, Henderson DG: Encapsulated intramedullary tumor involving the whole spinal cord from medulla to conus: Complete enucleation with recovery. Surg Gynec Obstet 68:814-819, 1939

6. McCormick PC, Torres R, Post KD, Stein BM: Intramedullary ependymoma of the spinal cord. J Neurosurg 72:523-532, 1990

7. Nakamura S, Yamada H, Tajima M, Yoshida J, Kobayashi T, Kagemaya N: Intramedullary tumor involving from brain stem to conus medullaris. Shoni No Noshinkei 5:199-203,1980

8. Peker S, Ozgen S, Ozek MM, Pamir MN. Surgical treatment of intramedullary spinal cord ependymomas: Can outcome be predicted by tumor parameters? J Spinal Disord Tech 17: 516-521, 2004

9. Raco A, Esposito V, Lenzi J, Piccirilli M, Deflini R, Cantore G: Long-term follow-up of intramedullary spinal cord tumors: A series of 202 cases. Neurosurgery 56:972-981, 2005.

10. Sarikaya S, Acikgöz B, Tekkök IH, Güngen YY: Conus ependymoma with holocord syringohydromyelia and syringobulbia. J Clin Neurosci 14:901-904, 2007

11. Schittenhelm J, Ebner FH, Tatagiba $M$, Wolff $M$, Nagele T, Meyermann R, Mittelbronn M: Holocord pilocytic astrocytoma. Case report and review of the literature. Clin Neurol Neurosurg 111:203-207, 2009

12. Tanaka $H$, Shimizu H, Ishijima B, Nakamura Y: Myxopapillary ependymoma of the filum terminale with a holocord cyst: A case report. No Shinkei Geka 14:997-1003, 1986

13. Tedeschi G, Spaziante R, Corriero G, Gambardella A, Pettinato G: A case of pan-medullary astrocytoma in a child. Neurochirurgia (Stuttg) 25:27-30, 1982

14. Tobias ME, McGirl MJ, Chaichana KL, Goldstein IM, Kothbauer KF, Epstein F, Jallo Gl: Surgical management of long intramedullary spinal cord tumors. Child Nerv Syst 24: 219-223 2008 